Manuscript Number:

Title: IN VITRO ASSESSMENT OF THE COMBINED EFFECT OF EICOSAPENTAENOIC ACID, GREEN TEA EXTRACT AND CURCUMIN C3 ON PROTEIN LOSS IN C2C12 MYOTUBES

Article Type: Full Length Article

Keywords: muscle protein atrophy; EPA; curcumin; green tea extract

Corresponding Author: Dr. Kamran Ali Mirza, Ph.D.

Corresponding Author's Institution: Aston University

First Author: Kamran Ali Mirza, Ph.D.

Order of Authors: Kamran Ali Mirza, Ph.D.; Menghua Luo, MD, PhD; Suzette L Pereira, Ph.D; Anne C

Voss, PhD; Tapas Das, Ph.D; Michael J Tisdale, Ph.D, D.Sc.

Abstract: ABSTRACT

BACKGROUND: EPA has been clinically shown to reduce muscle wasting during cancer cachexia. This study investigates whether curcumin or green tea extract (GTE) enhances the ability of low doses of eicosapentaenoic acid (EPA) to reduce loss of muscle protein in an in vitro model.

METHODS: A low dose of EPA with minimal anti-cachectic activity was chosen to evaluate any potential synergistic effect with curcumin or GTE. Depression of protein synthesis and increase in degradation was determined in C2C12 myotubes in response to tumour necrosis factor- $\alpha$ (TNF- $\alpha$ ) and proteolysisinducing factor (PIF).

RESULTS: EPA $(50 \mu \mathrm{M})$ or curcumin $(10 \mu \mathrm{g} \mathrm{ml}-1)$ alone had little effect on protein degradation caused by PIF but the combination produced complete inhibition, as did the combination with GTE $(10 \mu \mathrm{g} \mathrm{ml-}$

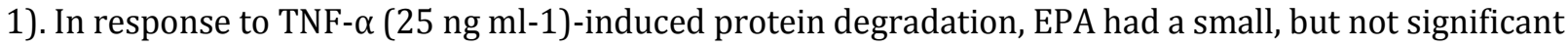
effect on protein degradation, however, when curcumin and GTE were combined with EPA the effect was enhanced. EPA completely attenuated the depression of protein synthesis caused by TNF- $\alpha$, but not that caused by PIF. The combination of EPA with curcumin produced a significant increase in protein synthesis to both agents. GTE alone or in combination with EPA had no effect on the depression of protein synthesis by TNF- $\alpha$, but did significantly increase protein synthesis in PIF-treated cells. Both TNF- $\alpha$ and PIF significantly reduced myotube diameter from 17 to $13 \mu \mathrm{m}$ for TNF- $\alpha(23.5 \%)$ and 15 $\mu \mathrm{m}(11.8 \%)$ for PIF However the triple combination of EPA, curcumin and GTE returned diameters to values not significantly different from the control.

CONCLUSION: These results suggest that either curcumin or GTE or the combination could enhance the anticatabolic effect of EPA on lean body mass. 


\section{Aston University}

Aston Triangle

Birmingham B4 7ET

United Kingdom

Tel $+44(0) 1212043000$

www.aston.ac.uk

Dear Editor,

I enclose a manuscript entitled "IN VITRO ASSESSMENT OF THE COMBINED EFFECT OF EICOSAPENTAENOIC ACID, GREEN TEA EXTRACT AND CURCUMIN C3 ON PROTEIN LOSS IN $\mathrm{C}_{2} \mathrm{C}_{12}$ MYOTUBES" Which I wish to be considered for publication in the Journal "EXPERIMENTAL CELL RESEARCH" I can confirm that the material is original research and has not been previously published or has not been submitted for publication elsewhere while under consideration.

Yours Sincerely

Dr. Kamran Ali Mirza

Nutritional Biomedicine, School of Life and Health Sciences,

Aston University, Birmingham, B4 7ET, UK

Email:k.a.mirza@aston.ac.uk

Telephone:+44 (0) 1212044193

Fax: +44 (0) 1212043743 


\section{Highlights}

EPA has been clinically shown to reduce muscle wasting during cancer cachexia.

EPA or curcumin alone had little effect on protein degradation caused by PIF but the combination produced complete inhibition, as did the combination with GTE.

The combination of EPA with curcumin produced a significant increase in protein synthesis caused by TNF- $\alpha$ and PIF.

TNF- $\alpha$ and PIF significantly reduced myotube diameter, however the triple combination of EPA, curcumin and GTE returned diameters to values not significantly different from the control.

These results suggest that either curcumin or GTE or the combination could enhance the anticatabolic effect of EPA on lean body mass. 


\title{
IN VITRO ASSESSMENT OF THE COMBINED EFFECT OF EICOSAPENTAENOIC ACID, GREEN TEA EXTRACT AND CURCUMIN C3 ON PROTEIN LOSS IN $\mathrm{C}_{2} \mathrm{C}_{12}$ MYOTUBES
}

\begin{abstract}
Kamran A. Mirza*1, Menghua Luo ${ }^{2}$, Suzette Pereira ${ }^{2}$, Anne Voss $^{2}$, Tapas Das $^{2}$ and Michael J. Tisdale ${ }^{1}$ ${ }^{1}$ Nutritional Biomedicine, School of Life and Health Sciences,
\end{abstract} Aston University, Birmingham B4 7ET, UK

${ }^{2}$ Abbott Nutrition, Research \& Development, Columbus, Ohio, USA

*corresponding author: k.a.mirza@aston.ac.uk

Running title- Effect of EPA, curcumin and GTE on muscle protein. 


\section{ABSTRACT}

BACKGROUND: EPA has been clinically shown to reduce muscle wasting during cancer cachexia. This study investigates whether curcumin or green tea extract (GTE) enhances the ability of low doses of eicosapentaenoic acid (EPA) to reduce loss of muscle protein in an in vitro model.

METHODS: A low dose of EPA with minimal anti-cachectic activity was chosen to evaluate any potential synergistic effect with curcumin or GTE. Depression of protein synthesis and increase in degradation was determined in $\mathrm{C}_{2} \mathrm{C}_{12}$ myotubes in response to tumour necrosis factor- $\alpha$ (TNF- $\alpha)$ and proteolysis-inducing factor (PIF).

RESULTS: EPA $(50 \mu \mathrm{M})$ or curcumin $\left(10 \mu \mathrm{g} \mathrm{ml}{ }^{-1}\right)$ alone had little effect on protein degradation caused by PIF but the combination produced complete inhibition, as did the

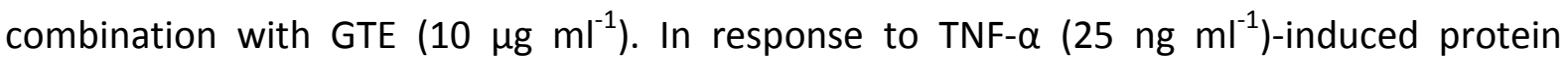
degradation, EPA had a small, but not significant effect on protein degradation, however, when curcumin and GTE were combined with EPA the effect was enhanced. EPA completely attenuated the depression of protein synthesis caused by TNF- $\alpha$, but not that caused by PIF. The combination of EPA with curcumin produced a significant increase in protein synthesis to both agents. GTE alone or in combination with EPA had no effect on the depression of protein synthesis by TNF- $\alpha$, but did significantly increase protein synthesis in PIF-treated cells. Both TNF- $\alpha$ and PIF significantly reduced myotube diameter from 17 to $13 \mu \mathrm{m}$ for TNF$\alpha(23.5 \%)$ and $15 \mu \mathrm{m}(11.8 \%)$ for PIF However the triple combination of EPA, curcumin and GTE returned diameters to values not significantly different from the control.

CONCLUSION: These results suggest that either curcumin or GTE or the combination could enhance the anticatabolic effect of EPA on lean body mass.

Keywords: muscle protein atrophy; EPA; curcumin; green tea extract. 


\section{INTRODUCTION}

At least half of all cancer patients suffer from cachexia, a progressive wasting syndrome involving loss of both adipose tissue and skeletal muscle, which eventually leads to the death of the patient (Bachmann et al, 2008; Dewys et al, 1980). Although anorexia is initially present, provision of excess calories alone has a limited effect on weight loss (Koretz 2007), and is considered to arise from the catabolic effect of cytokines such as tumour necrosis factor- $\alpha$ (TNF- $\alpha$ ) and tumour products such as proteolysis-inducing factor (PIF). Thus treatment necessitates inclusion of an anti-catabolic agent in addition to nutritional support.

Eicosapentaenoic acid (EPA), a constituent of fish oil, is one such anti-catabolic agent shown to reduce production of the cytokine interleukin (IL)- 6 but not TNF- $\alpha$ in serum, and the urinary excretion of PIF in cachectic patients with pancreatic cancer (Barber et al, 2001). EPA has also been shown to attenuate the catabolic effect of PIF, both in vitro (Smith et al, 1999), and in vivo (Hussey and Tisdale, 1999). In vitro (Smith et al, 1999) and in vivo studies in mice (Smith et al, 2004) suggest that EPA is effective in attenuation of the increased protein degradation in cachexia. It has no effect alone on protein synthesis, although its effect can be enhanced with casein and amino acids (Smith et al, 2004). For this reason commercial EPA containing oral nutrition supplements (EPA-ONS) for the treatment of cancer cachexia have fish oil combined with high protein levels (Barber et al, 1999). When consumed at $2.1 \mathrm{~g} \mathrm{EPA} \mathrm{day}^{-1}$ such a preparation is effective in increasing body weight in patients with pancreatic cancer, as well as increasing lean body mass (Barber et al, 1999). However, in larger scale clinical trials consumption was much less (1.5 g EPA day ${ }^{-1}$ )and the beneficial effect was reduced (Fearon et al, 2003), although a study of patients with non- 
small cell lung cancer (NSCLC) undergoing multimodality treatment showed that EPA-ONS intake of $1 \mathrm{~g} \mathrm{day}^{-1}$ had a better maintenance of body weight (van der Meij et al, 2010), fat free mass, quality of life, and performance status than standard ONS (van der Meij et al, 2012). In another study of NSCLC patients undergoing chemotherapy, better weight maintenance and FFM gain were shown with EPA-ONS (72\% of patients consumed 2.2 g/day) compared to the control group (Sanchez et al, 2014). An esophageal cancer surgery study showed that all aspects of body composition were maintained with EPA-ONS while patients receiving a standard supplement lost significant amounts of FFM (Ryan et al, 2009).

With increased cost, poor patient compliance and limited sources of fish oil, methods of increasing the activity of EPA would be beneficial. For example, the activity of EPA could be enhanced if combined with other anti-catabolic agents. In this study two agents previously shown to exert anti-cachexia activity in experimental models were studied; curcumin (diferuloylmethane) (Siddiqui et al, 2009) and green tea extract (GTE) containing epigallocatechin-3-gallate-(EGCg) and other catechins (Wang et al, 2011). Both curcumin (Wyke et al, 2004) and EGCg (Mirza et al, 2014) were shown to attenuate the catabolic effect of PIF and TNF- $\alpha$ on muscle protein degradation in vitro and this study investigates their ability to act in combination with EPA to attenuate the depression of protein synthesis and protein degradation produced by these catabolic factors in $\mathrm{C}_{2} \mathrm{C}_{12}$ murine myotubes. 


\section{METHODS AND METHODS}

\section{Materials}

The chymotrypsin substrate (N-Succinyl-Leu-Leu-Val-Tyr-7-Amido-4-methylcoumarin) was obtained from Sigma (Dorset, UK). L-[2,6- $\left.{ }^{3} \mathrm{H}\right]$ phenylalanine (sp.act.3.7 TBqmmol ${ }^{-1}$ ) was from Perkin Elmer (Cambridge, UK). Mouse monoclonal antibodies to 20S proteasome $\alpha$-subunits and p42 were from Affiniti Research Products (Exeter, UK). Fatty acid free BSA, tumour necrosis factor (TNF- $\alpha$ ), polyclonal rabbit antibody to mouse $\beta$-actin, chymotrypsin substrate (N-Succinyl-Leu-Leu-Val-Tyr-7-Amido-4-methylcoumarin) and lactacystin were purchased from Sigma-Aldridge (Dorset, UK). Peroxidase-conjugated sheep antirabbit and antimouse antibodies were purchased from GE Healthcare (Bucks, UK), as were Hybond A nitrocellulose membranes. Enhanced chemiluminescence $(E C L)$ development kits were from Pierce through Thermo Fischer Scientific (Northumberland, UK). Rabbit polyclonal antisera to atrogin-1/MAFbx, and goat polyclonal antisera to MuRF1 were purchased from Santa Cruz Biotechnology, Inc. (Santa Cruz, CA, USA). EPA was added to fatty acid free BSA in doubled distilled water (g/g) and neutralised with equimolar $\mathrm{NaHCO}_{3}$. Green tea extract (Sunphenon 90D) was purchased from Taiyo international, (Tokyo, Japan). Curcumin C3 was from Sabinsa Corporation, NJ, USA. EPA (free acid) (98 $\geq$ pure) was from Enzo Life Sciences (Exeter, UK).

\section{Measurement of proteasome activity}

Functional 205 proteasome activity was determined as the "chymotrypsin-like" enzyme activity by the release of 7-amino-4-methylcoumarin (AMC) from the fluorogenic peptide succinyl-LLVY-7-AMC as previously described (Whitehouse and Tisdale 2003). Activity was measured in the absence and presence of the specific proteasome inhibitor lactacystin 
$(10 \mu \mathrm{M})$ and only lactacystin suppressible activity was considered to be proteasome specific.

The activity was normalised to the protein content which was determined using the Bradford assay (Sigma).

\section{Western blotting}

Myotubes were scraped from the substratum and washed with PBS prior to sonication at $4^{\circ} \mathrm{C}$ in $20 \mathrm{mM}$ Tris- $\mathrm{HCl}(\mathrm{pH} 7.4), 2 \mathrm{mM} \mathrm{ATP}, 5 \mathrm{mM} \mathrm{MgCl} 2$ and $1 \mathrm{mM}$ DTT. Cytosolic protein (10$15 \mu \mathrm{g}$ ) formed by centrifugation at $18000 \mathrm{~g}$ for $10 \mathrm{~min}$ at $4^{\circ} \mathrm{C}$ was resolved on $10 \%$ SDSPAGE at $180 \mathrm{~V}$ for $1 \mathrm{~h}$, followed by transference onto $0.45 \mathrm{~mm}$ nitrocellulose membranes at $300 \mathrm{~mA}$ for $1 \mathrm{~h}$, which were then blocked with 5\% Marvel in Tris-buffered saline, pH 7.5, at $4{ }^{\circ} \mathrm{C}$ overnight. Both primary and secondary antibodies were used at a dilution of 1:1000. Incubation with primary antibodies was overnight at $4^{\circ} \mathrm{C}$, while with secondary antibodies it was for $1 \mathrm{~h}$ at room temperature, and development was by ECL. Blots were scanned by a densitometer to quantitate differences, and were reported relative to an actin loading control.

\section{Measurement of total protein degradation}

This was performed as previously described (Whitehouse and Tisdale, 2003). Briefly myotubes were labelled for $24 \mathrm{~h}$ with $\mathrm{L}-\left[2,6^{-3} \mathrm{H}\right]$ phenylalanine and then washed extensively in PBS followed by a further incubation for $2 \mathrm{~h}$ to eliminate degradation of short-lived proteins. Protein degradation was determined over a $24 \mathrm{~h}$ period in the presence of $2 \mathrm{mM}$ non-labelled phenylalanine to prevent reincorporation of radioactivity, as a fraction of the total radioactivity incorporated into the myotubes in the presence or absence of PIF and TNF- $\alpha$. Some myotubes were also treated with GTE, Curcumin and EPA for $2 \mathrm{~h}$ prior to PIF or 
TNF- $\alpha$ addition. The radioactivity released was expressed as a fraction of the total incorporated into the myotubes.

\section{Measurement of protein synthesis}

Myotubes were formed in six-well multiwell dishes, and were supplemented with DMEM without HS for $18 \mathrm{~h}$ before experimentation (Eley and Tisdale, 2007). Curcumin, GTE and EPA were added to the cultures $2 \mathrm{~h}$ before adding PIF and TNF- $\alpha$. Protein synthesis was carried out after $4 \mathrm{~h}$ incubation with PIF and TNF- $\alpha$. Protein synthesis was determined by the incorporation of $\mathrm{L}-\left[2,6-{ }^{3} \mathrm{H}\right]$ phenylalanine into myotubes over a $4 \mathrm{~h}$ periods described in the figure legend. Protein synthesis was calculated as the radioactivity incorporated into acid (0.2 M perchloric acid) insoluble material as a percentage, compared with control cultures with no serum.

\section{Measurement of myotube diameter}

$\mathrm{C}_{2} \mathrm{C}_{12}$ myotubes were differentiated in DMEM medium with $2 \%$ horse serum. EPA, Curcumin and GTE were added to the cultures $2 \mathrm{~h}$ before adding PIF and TNF- $\alpha$ on day 1 , and the addition was repeated every 2 days. Myotube diameter was measured using an inverted widefield fluorescent microscope (Leica Microsystems $\mathrm{GmbH}$, Germany). Analysis of the images was obtained using Leica application suit AF software.

\section{Statistical analysis}

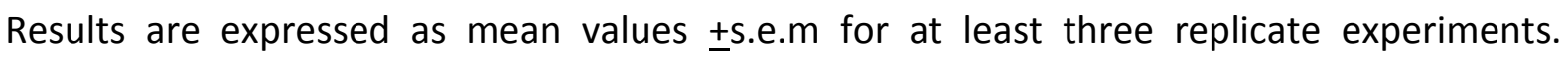
Differences in mean values between group were determined by one-way ANOVA followed by Tukey-Kramer multiple comparison test and $p$-values $<0.05$ were considered significant. 


\section{RESULTS}

Previous studies (Wyke et al, 2004) have shown the optimal concentration of PIF to initiate protein degradation in vitro to be $4.2 \mathrm{nM}$, while for TNF- $\alpha$ the optimal concentration is 25 $\mathrm{ng} \mathrm{ml} \mathrm{m}^{-1}$ (Mirza et al, 2014). The effect of increasing concentration of curcumin on protein degradation induced by TNF- $\alpha$ and PIF is shown in Fig $1[A, B]$. The minimum effective concentration to attenuate protein degradation by both agents was $10 \mu \mathrm{g} \mathrm{ml}^{-1}$. For GTE the concentrations were 10 and $5 \mu \mathrm{g} \mathrm{m}{ }^{-1}$ for TNF- $\alpha$ and PIF respectively (Fig 1C, D). A concentration of $10 \mu \mathrm{g} \mathrm{ml}^{-1}$ for both curcumin and GTE was chosen for further studies.

The effect of combination of curcumin and GTE with EPA $(50 \mu \mathrm{M})$ on protein degradation induced by PIF and TNF- $\alpha$ is shown in Fig 2. For PIF (Fig 2A) EPA alone had a small, but not significant effect on protein degradation, which was also shown by curcumin $\left(10 \mu \mathrm{g} \mathrm{ml}^{-1}\right)$, but the combination of EPA with curcumin totally attenuated PIF-induced protein degradation. A similar effect was seen with GTE at $10 \mu \mathrm{gl}^{-1}$ (Fig 2B), with the combination with EPA producing complete inhibition of PIF-induced protein degradation. For TNF- $\alpha$, EPA alone attenuated protein degradation to control values, (Fig 2D), and this was further reduced in combination with curcumin (Fig 2C). GTE alone significantly reduced protein degradation induced by TNF- $\alpha$ (Fig 2D) and in combination with EPA, values were reduced below those in the negative control (Fig 2D).

The major degradative pathway for muscle protein in cachexia is considered to be the ubiquitin proteasome system. The functional activity of the proteasome can be measured as the chymotrypsin-like enzyme activity located on the $\beta 5$-subunit of the $20 \mathrm{~S}$ proteasome. The activity of this enzyme was enhanced by both TNF- $\alpha$ and PIF (Fig 3A, B), and reduced below the negative control by EPA, curcumin and GTE as well as combinations. 
TNF- $\alpha$ also increased protein expression of the $20 \mathrm{~S}$ proteasome subunits as well as p42, an ATPase subunit of the $19 \mathrm{~S}$ regulator, (Fig 4A, B) and the E3 ligases MuRF1 and MAFbx (Fig 4C, D), as determined by western blotting and these were reduced to or below the negative control by EPA, curcumin, GTE and the combinations. Similar results were obtained with PIF (data not shown).

Both TNF- $\alpha$ and PIF depressed protein synthesis by $20 \%$ (Fig 5). Interestingly EPA completely attenuated the depression of protein synthesis induced by TNF- $\alpha$ (Fig 5A), but had no significant effect on that induced by PIF (Fig 5B), as previously reported (Smith et al, 1999), possibly reflecting the different mechanism of action of the two agents. Curcumin alone was unable to reverse the depression of protein synthesis by TNF- $\alpha$ (Fig 5A) or PIF (Fig $5 B)$, but in combination with EPA there was a significant increase in protein synthesis. Neither GTE alone, or in combination with EPA had any significant effect on the depression of protein synthesis by TNF- $\alpha$, while for PIF only the combination produced a significant increase of protein synthesis over that of PIF alone (Fig 5B). The effect of TNF- $\alpha$ and PIF on myotube diameter is shown in Fig 6. For TNF- $\alpha$ myotube diameter initially decreased and then stabilized at a significantly lower level than control (Fig 6A), However, myotube diameter was significantly increased when TNF- $\alpha$ was combined with EPA, curcumin and GTE, such that values did not differ significantly from non-treated control (Fig 6A). A similar result was seen with PIF (Fig 6B), which significantly reduced myotube diameter alone, but this was restored to control values in the presence of EPA, curcumin and GTE. 


\section{DISCUSSION}

Treatment for cachexia is currently limited and mainly involves use of megestrol acetate (Megace), an appetite stimulant which has been reported to increase body weight (Mantovani et al, 2011). However, this weight gain has been shown to be due to fat and water increases and not lean body mass (Loprinzi et al, 1993). In contrast EPA, has been shown to increase lean body mass, with no change in fat mass in patients with pancreatic cancer (Barber et al, 1999). There are several potential anti-cachectic agents, which have been identified from animal models, which have not yet been clinically evaluated. Among them are curcumin (Siddiqui et al, 2009) and GTE (Wang et al, 2011), both natural products found in turmeric and green tea respectively. These agents could potentially be used as alternative to EPA or combined with EPA to enhance its effectiveness as an anti-cachectic agent. To evaluate this possibility this study has employed murine myotubes as a surrogate model of skeletal muscle and muscle protein degradation and depressed protein synthesis have been initiated with two catabolic agents, TNF- $\alpha$ and PIF, both of which have been suggested to be important mediators of muscle loss in cancer patients with cachexia (Tisdale, 2009). Based on previous studies, a low dose of EPA with minimal anti-cachectic activity has been chosen to evaluate potential synergistic effect in combination with curcumin or GTE.

For protein degradation induced by both PIF and TNF- $\alpha$, both curcumin and GTE enhanced the anti-catabolic effect of EPA at minimally effective concentrations. A similar effect was seen on the major components of the ubiquitin proteasome pathway, with both TNF- $\alpha$ and PIF enhancing expression of the $20 \mathrm{~S}$ and 195 proteasome subunits as well as the ubiquitin ligases MuRF1 and MAFbx, which was attenuated by EPA, curcumin, GTE and the combination. We have also determined muscle protein atrophy by measuring myotube 
diameter, which was significantly reduced by both TNF- $\alpha$ and PIF and restored by a combination of EPA, curcumin and GTE. Interestingly curcumin has been shown to block muscle proteolysis in septic rats without affecting the expression of atrogin-1 and MuRF1 (Poylin et al, 2008). In addition to proteasome activity, protein breakdown by both calpain and cathepsin- $\mathrm{L}$ were also reduced by curcumin. In contrast, in mice bearing the cachexiainducing MAC16 tumour, curcumin attenuated loss of muscle protein by inhibiting $20 \mathrm{~S}$ proteasome expression and reducing expression of MuRF1 and MAFbx (Siddiqui et al, 2009). Both EPA (Whitehouse and Tisdale, 2003) and curcumin (Alamdari, 2009; Thaloor et al. 1999) attenuate protein degradation through the ubiquitin-proteasome pathway via the nuclear transcription factor NF-KB. Both inhibit the upstream kinase IKB kinase (IKK) thus preventing phosphorylation of inhibitor $\kappa B \alpha(I \kappa B \alpha)$ in the cytosol, stabilising the NF- $\mathrm{KB} / \mathrm{I} \mathrm{KB}$ complex and preventing nuclear migration of NF-KB, which upregulates proteasomal expression (Wyke et al, 2004). However, curcumin also directly inhibits the chymotrypsinlike activity of the $20 \mathrm{~S}$ proteasome (Milacic et al, 2008), a feature also seen with the major polyphenols found in GTE (Smith et al, 2002). In addition Waag et al, (2011) has shown that these polyphenols also regulate expression of NF-kB, suggesting multiple mechanisms by which myofibrillar protein degradation may be suppressed. Both PIF and TNF- $\alpha$ depressed protein synthesis by the same amount and for TNF- $\alpha$ this depression in protein synthesis was attenuated by EPA, but not for PIF. This may be indicative of different mechanisms for depression of protein synthesis by the two agents, although studies to date suggest that they also share similar mechanisms by inducing autophosphorylation of the RNA-dependent protein kinase (PKR), which increases phosphorylation of eukaryotic initiation factor $2 \alpha$ (elF $2 \alpha$ ), which depresses protein synthesis by inhibiting binding of initiator methionyl-tRNA to the 40S ribosomal subunit (Eley and Tisdale, 2007; Eley et al, 2008). 
These results suggest that the combinations of EPA with either curcumin or GTE, or both, would be effective in attenuating muscle protein degradation in cancer cachexia induced either by TNF- $\alpha$ or PIF.

\section{Acknowledgements}

This work was supported by a grant from Abbott Nutrition, Columbus, $\mathrm{OH}, \mathrm{USA}$. Kamran Ali Mirza and Michael J Tisdale declare that they have no conflict of interest. Menghua Luo, Suzette Pereira, Anne C Voss, and Tapas Das are employees of Abbott Nutrition. 


\section{REFERENCES}

Alamdari N, O`Neal P, Hasselgren PO (2009) Curcumin and muscle wasting: a new role for an old drug? Nutrition 25: 125-129

Bachmann J, Heiligensetzer M, Krakowski-Roosen H, Büchler MW, Friess H, Martignoni ME (2008) Cachexia worsens prognosis in patients with resectable pancreatic cancer. J Gastrointest Surg 12: 1193-1201

Barber MD, Ross JA, Voss AC, Tisdale MJ, Fearon KC (1999) The effect of an oral nutritional supplement enriched with fish oil on weight-loss in patients with pancreatic cancer. Br J Cancer 81: 80-86

Barber MD, Fearon KC, Tisdale MJ, McMillan DC, Ross JA (2001) Effect of a fish oil-enriched nutritional supplement on metabolic mediators in patients with pancreatic cancer cachexia. Nutr Cancer 40: 118-124

Eley HL and Tisdale MJ (2007) Skeletal muscle atrophy, a link between depression of protein synthesis and increase in degradation. J Biol Chem 282: 7087-97

Eley HL, Russell ST, Tisdale MJ (2008) Attenuation of depression of muscle protein synthesis induced by lipopolysaccharide, tumor necrosis factor, and angiotensin II by betahydroxy-beta-methylbutyrate. Am J Physiol Endocrinol Metab 295: E1409-E1416 
Dewys WD, Begg C, Lavin PT, Band PR, Bennett JM, Bertino JR et al (1980) Prognostic effect of weight loss prior to chemotherapy in cancer patients. Eastern Cooperative Oncology Group. Am J Med 69: 491-497

Fearon KC, Von Meyenfeldt MF et al (2003) Effect of a protein and energy dense N-3 fatty acid enriched oral supplement on loss of weight and lean tissue in cancer cachexia: a randomised double blind trial. Gut 52: 1479-86

Hussey HJ1, Tisdale MJ (1999) Effect of a cachectic factor on carbohydrate metabolism and attenuation by eicosapentaenoic acid. Br J Cancer 80: 1231-35

Koretz RL (2007) Should patients with cancer be offered nutritional support: does the benefit outweigh the burden? Eur J Gastroenterol Hepatol 19: 379-382

Loprinzi CL, Schaid DJ, Dose AM, Burnham NL, Jensen MD (1993) Body-composition changes in patients who gain weight while receiving megestrol acetate. J Clin Oncol 11: 152154

Mantovani G, Macciò A, Massa E, Madeddu C (2001) Managing cancer-related anorexia/cachexia. Drugs 61: 499-514

Milacic V, Banerjee S, Landis-Piwowar KR, Farkar FH, Majumdar AP, Dou QP (2008) Curcumin inhibits the proteasome activity in human colon cancer cells in vitro and in vivo. Cancer Res 68: 7283-92 
Mirza KA, Pereira SL, Edens NK, Tisdale MJ (2014) Attenuation of muscle wasting in murine $\mathrm{C}_{2} \mathrm{C}_{12}$ myotubes by epigallocatechin-3-gallate. J Cachexia Sarcopenia Muscle 5: 339345

Poylin V, Fareed MU, O'Neal P, Alamdari N, Reilly N, Menconi M, Hasselgren PO (2008) The NF-kappaB inhibitor curcumin blocks sepsis-induced muscle proteolysis. Mediators Inflamm 2008: 317851

Ryan AM, Reynolds JV, Healy L, Byrne M, Moore J, Brannelly N, McHugh A, McCormack D, Flood P (2009) Enteral nutrition enriched with eicosapentaenoic acid (EPA) preserves lean body mass following esophageal cancer surgery: results of a doubleblinded randomized controlled trial. Ann Surg 249: 355-363

Sanchex-Lara K, Turcott JG, Juarez-Hernandez E, Nunez-Valencia C, Villanueva G, Guevara P, De la Torre Vallejo, Mohar A, Arrieta O (2014) Effects of an oral nutritional supplement containing eicosapentaenoic acid on nutritional and clinical outcomes in patietns with advanced non-small cell lung cancer: randomised trial. Clin Nutr 33: $1017-1023$

Siddiqui RA, Hassan S, Harvey KA, Rasool T, Das T, Mukerji P, DeMichele S (2009) Attenuation of proteolysis and muscle wasting by curcumin c3 complex in MAC16 colon tumour-bearing mice. $\mathrm{Br} J$ Nutr 102: 967-75 
Smith HJ, Lorite MJ, Tisdale MJ (1999) Effect of a cancer cachectic factor on protein synthesis/degradation in murine $\mathrm{C}_{2} \mathrm{C}_{12}$ myoblasts: modulation by eicosapentaenoic acid. Cancer Res 59: 5507-5513

Smith DM, Wang Z, Kazi A, Li LH, Chan TH, Dou QP (2002) Synthetic analogs of green tea polyphenols as proteasome inhibitors. Mol Med 8: 382-92

Smith HJ, Greenberg NA, Tisdale MJ (2004) Effect of eicosapentaenoic acid, protein and amino acids on protein synthesis and degradation in skeletal muscle of cachectic mice. $\mathrm{Br} J$ Cancer 91: 408-412

Thaloor D, Miller KJ, Gephart J, Mitchell PO, Pavlath GK (1999) Systemic administration of the NF-kappaB inhibitor curcumin stimulates muscleregeneration after traumatic injury. Am J Physiol 277: C320-9

Tisdale MJ (2009) Mechanisms of cancer cachexia. Physiol Rev 89: 381-410

Van der Meij BS, Langius JA, Smit EF, Spreeuwenberg MD, von Blomberg BM et al (2010) Oral nutritional supplements containing (n-3) polyunsaturated fatty acids affect the nutritional status of patients with stage III non-small cell lung cancer during multimodality treatment. J Nutr 140: 1774-1780

Van der Meij BS, Langius JA, Spreeuwenberg MD, Slootmaker SM, Paul MA, Smit EF, van Leeuwen (2012) Oral nutritional supplements containing (n-3) polyunsaturated 
fatty acids affect quality of life and functional status in lung cacner patients during multimodality treatment: an RCT. Eur J Clin Nutr 66: 399-404

Wang H, Lai YJ, Chan YL, Li TL, Wu CJ (2011) Epigallocatechin-3-gallate effectively attenuates skeletal muscle atrophy caused by cancer cachexia. Cancer Lett 305: 40-49

Whitehouse AS, Tisdale MJ (2003) Increased expression of the ubiquitin-proteasome pathway in murine myotubes by proteolysis-inducing factor (PIF) is associated with activation of the transcription factor NF-kappaB. Br J Cancer 89: 1116-22

Wyke SM, Russell ST, Tisdale MJ (2004) Induction of proteasome expression in skeletal muscle is attenuated by inhibitors of NF-kappaB activation. Br J Cancer. 91: 17421750 
Figure 1. Total protein degradation in $C_{2} C_{12}$ myotubes in response to treatment TNF- $\alpha\left(25 \mathrm{ng} \mathrm{ml}^{-1}\right)(\mathrm{A}$, C) or PIF $(4.2 \mathrm{nM})(\mathrm{B}, \mathrm{D})$ in the presence of curcumin $(\mathrm{A}, \mathrm{B})$ or GTE $(\mathrm{C}, \mathrm{D})$. Protein degradation was determined by the release of $\left[{ }^{3} \mathrm{H}\right]$ phenylalanine from pre-labelled cells over a $24 \mathrm{~h}$ period. The experiment was repeated three times. Differences from the negative control with no additions is indicated as $* p<0.05$ and ${ }^{* * *} p<0.001$, while differences from TNF- $\alpha$ or PIF are shown as $\uparrow p<0.05$, ††, $p<0.01$ or $\mathrm{t \top \dagger} p<0.001$.

Figure 2. Total protein degradation in $C_{2} C_{12}$ myotubes in response to treatment with PIF (4.2 nM) (A, B) or TNF- $\alpha\left(25 \mathrm{ng} \mathrm{ml}^{-1}\right)(\mathrm{C}, \mathrm{D})$ in the presence of EPA $(50 \mu \mathrm{M})$ alone, or in the presence of curcumin $(10 \mu \mathrm{g} \mathrm{ml}-1)(\mathrm{A}, \mathrm{C})$ or GTE $\left(10 \mu \mathrm{g} \mathrm{ml^{-1 }}\right)(\mathrm{B}, \mathrm{D})$ over a $24 \mathrm{~h}$ period as described in methods. The experiment was repeated three times. Differences from the negative control with no additions is indicated as $* p<0.05$ or $* * * p<0.001$, while differences from PIF or TNF- $\alpha$ alone is shown as $\uparrow p<0.05$ or $\uparrow \uparrow p<0.01$ and $+\uparrow \dagger p<0.001$.

Figure 3. Proteasome chymotrypsin like enzyme activity in $\mathrm{C}_{2} \mathrm{C}_{12}$ myotubes after treatment for $24 \mathrm{~h}$ with TNF- $\alpha\left(25 \mathrm{ng} \mathrm{ml}^{-1}\right)(\mathrm{A})$ or PIF $(4.2 \mathrm{nM})(\mathrm{B})$ in the absence or presence of EPA (50 $\left.\mu \mathrm{M}\right)$, curcumin $\left(10 \mu \mathrm{g} \mathrm{m}^{-1}\right)$ and GTE $\left(10 \mu \mathrm{g} \mathrm{ml}^{-1}\right)$ alone, or in combination. The experiment was repeated three times. Difference from the negative control is indicated as $* * p<0.01$ and $* * * p<0.001$, while difference from TNF- $\alpha$ and PIF alone is shown as T†† $p<0.001$.

Figure 4. Western blots showing expression of the 20 s proteasome subunits (A), p42 (B), MuRF1 (C) and MAFbx (D) after treatment with TNF- $\alpha\left(25 \mathrm{ng} \mathrm{ml}^{-1}\right)$ for $24 \mathrm{~h}$ alone or with EPA (50 $\left.\mu \mathrm{M}\right)$, curcumin $\left(10 \mu \mathrm{g} \mathrm{ml}^{-1}\right)$ and GTE $\left(10 \mu \mathrm{g} \mathrm{ml}^{-1}\right)$ alone or in combination. Actin was used as a loading control. The densitometric analysis is the average of three separate western blots. Differences from control are

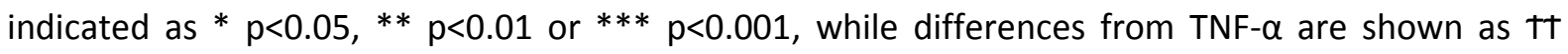
$p<0.01$ or $+\uparrow \uparrow p<0.001$. 
Figure 5. Protein synthesis in $C_{2} C_{12}$ myotubes after treatment for $4 \mathrm{~h}$ with TNF- $\alpha\left(25 \mathrm{ng} \mathrm{m}^{-1}\right.$ ) (A) or PIF $(4.2 \mathrm{nM})(B)$ in the absence or presence of EPA $(50 \mu \mathrm{M})$, curcumin $\left(10 \mathrm{ug} \mathrm{ml}^{-1}\right)$ or GTE $\left(10 \mu \mathrm{g} \mathrm{m}^{-1}\right)$ alone or in combination. The experiment was repeated three times. Differences from the negative control are indicated as ${ }^{*} p<0.05$, while differences from TNF- $\alpha$ or PIF are shown as $t p<0.05$ or t†p0.01.

Figure 6. Myotube diameter of $C_{2} C_{12}$ myotubes after treatment with TNF- $\alpha(A)$ or PIF (4.2 nM) alone, or in the presence of EPA $(50 \mu \mathrm{M})$, curcumin $\left(10 \mu \mathrm{g} \mathrm{ml}^{-1}\right)$ and GTE $\left(10 \mu \mathrm{g} \mathrm{m}^{-1}\right)$. Myotube diameter was measured on the days shown using an inverted widefield fluorescent microscope. The experiment was repeated three times where $n=12$. Differences from the negative control are shown as $* * * p<0.001$, while differences from TNF- $\alpha$ or PIF are shown as $\mathrm{TtT} p<0.001$. 
Fig $1 \mathrm{~A}$

A

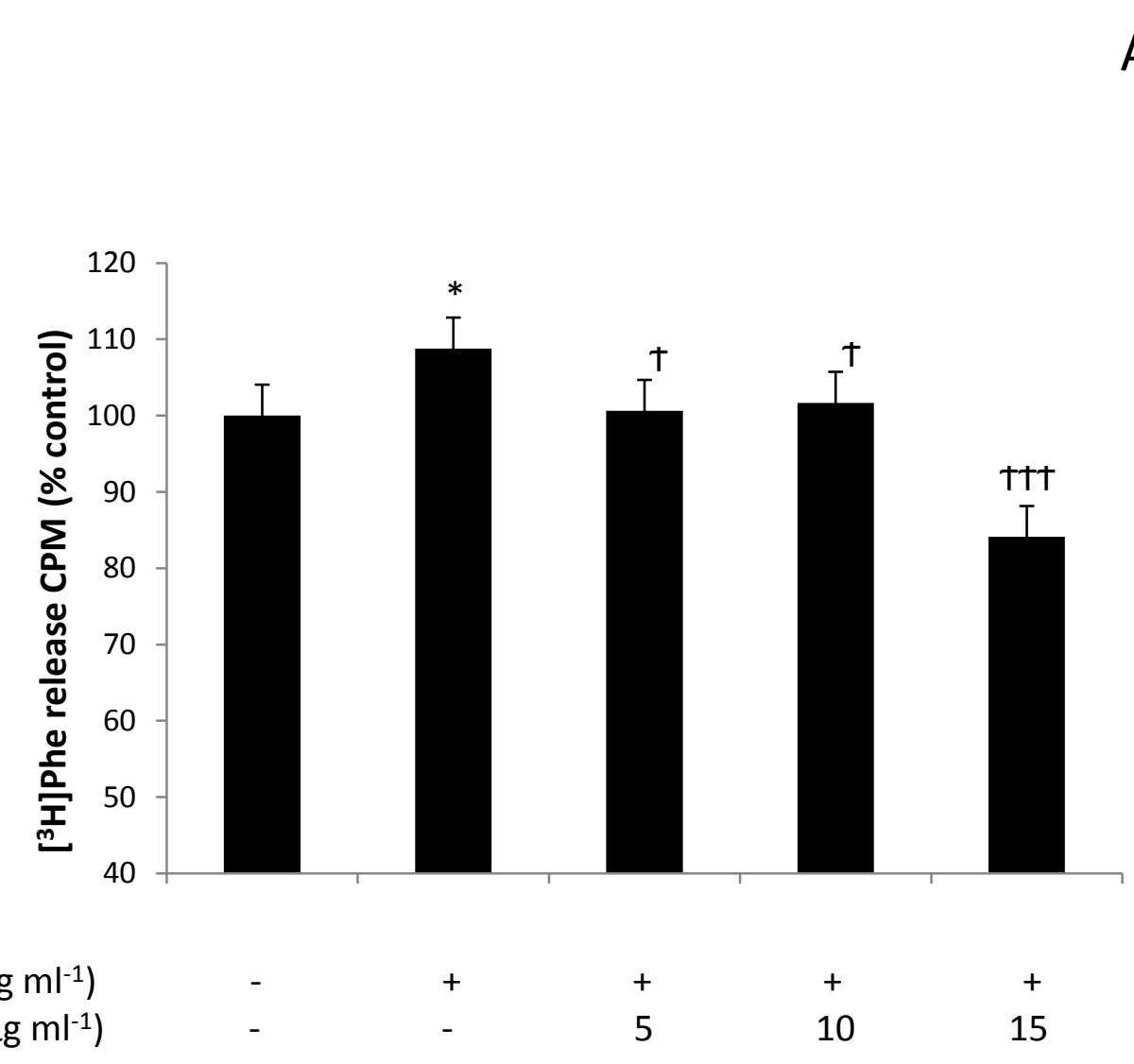

TNF- $\alpha\left(25 \mathrm{ng} \mathrm{ml}^{-1}\right)$

Curcumin ( $\mu \mathrm{g} \mathrm{ml}^{-1}$ ) 
Fig 1B

B

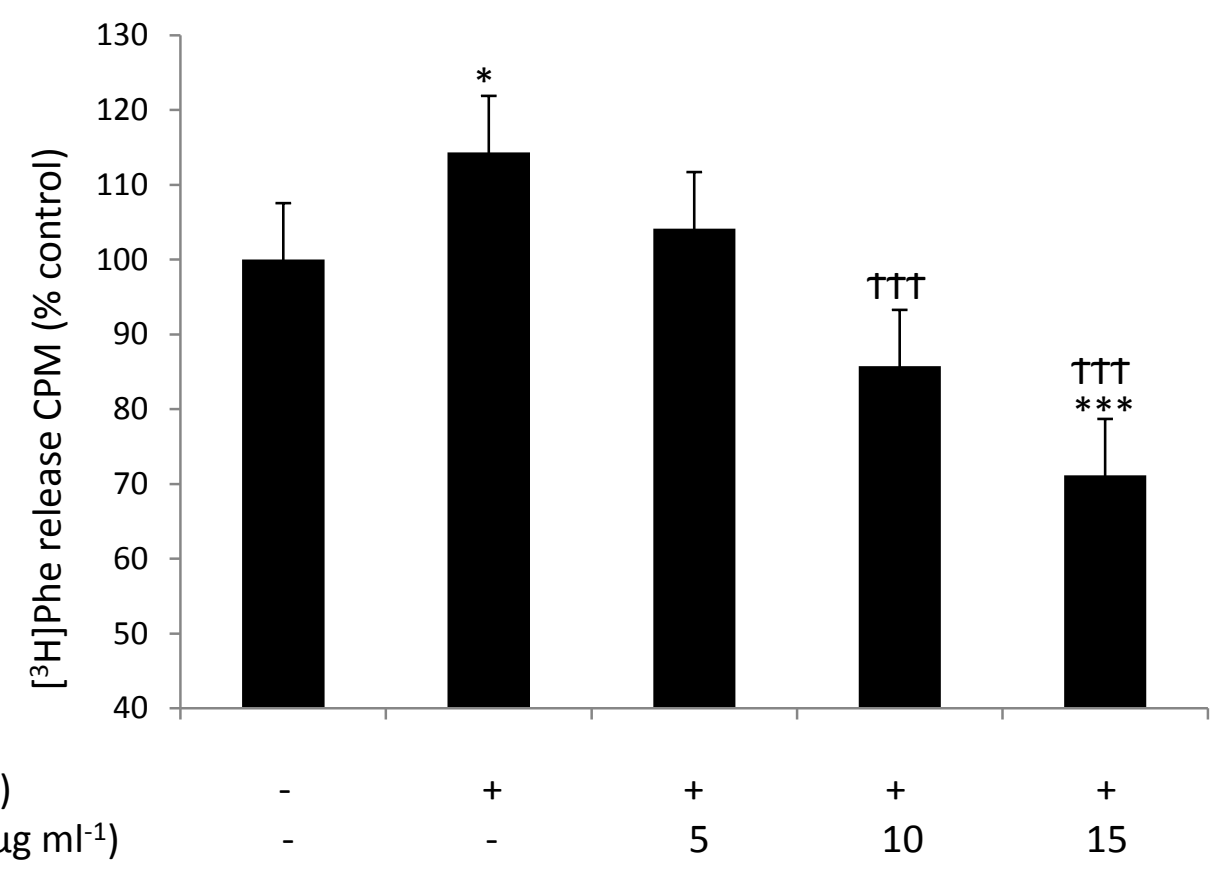


Fig $1 C$

C

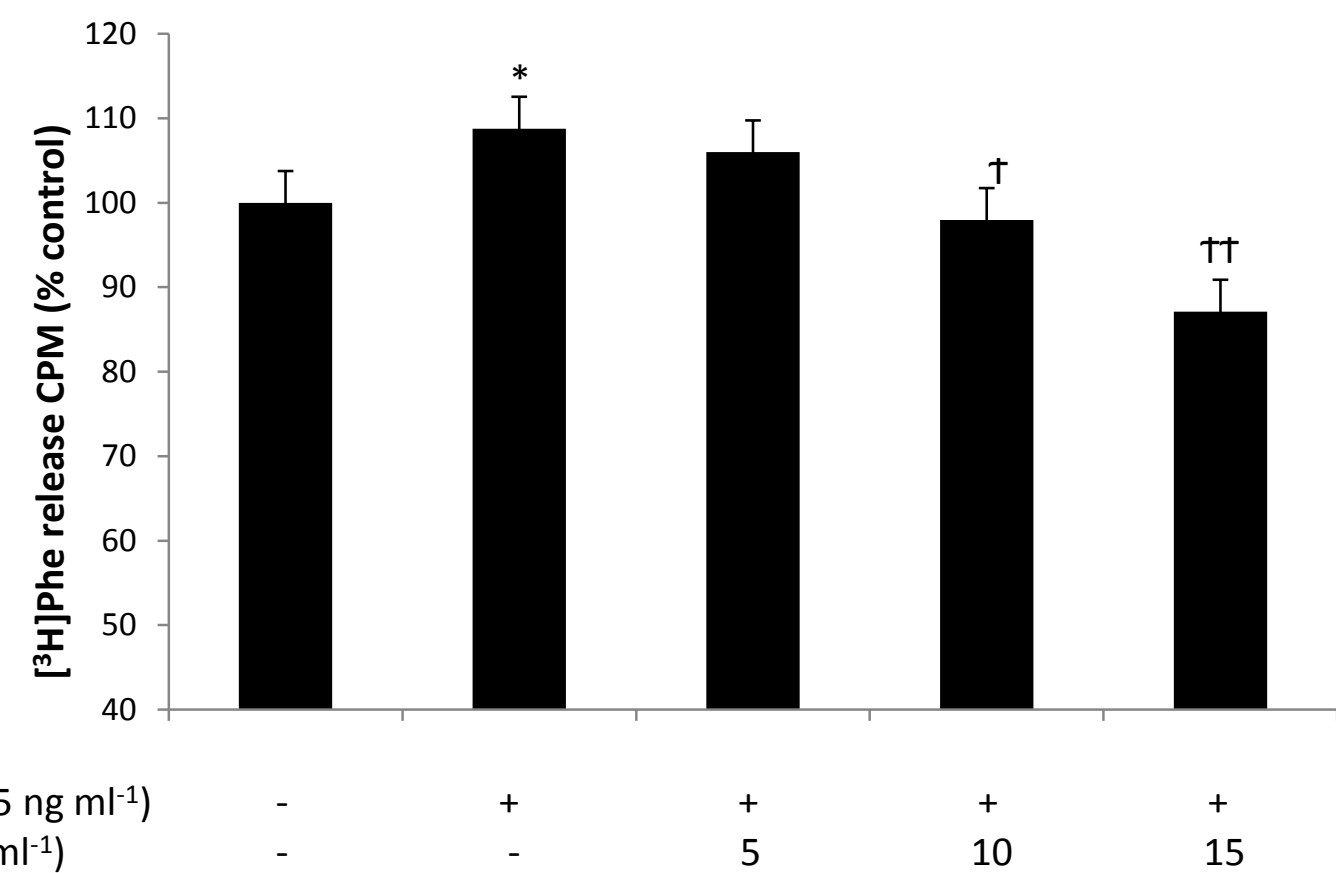

TNF- $\alpha\left(25 \mathrm{ng} \mathrm{ml}^{-1}\right)$

GTE ( $\left.\mu \mathrm{g} \mathrm{ml}^{-1}\right)$

15 
Fig 1D

D

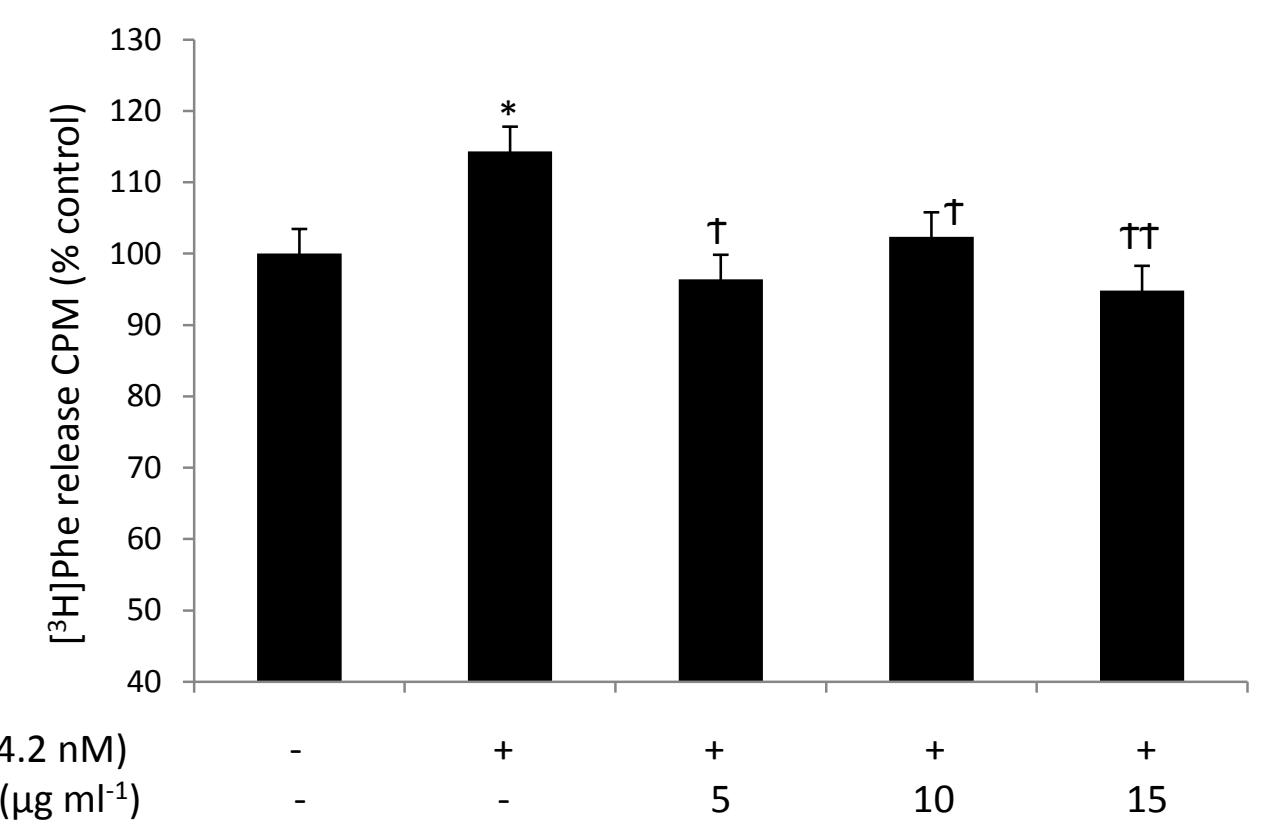


Fig $2 \mathrm{~A}$

A

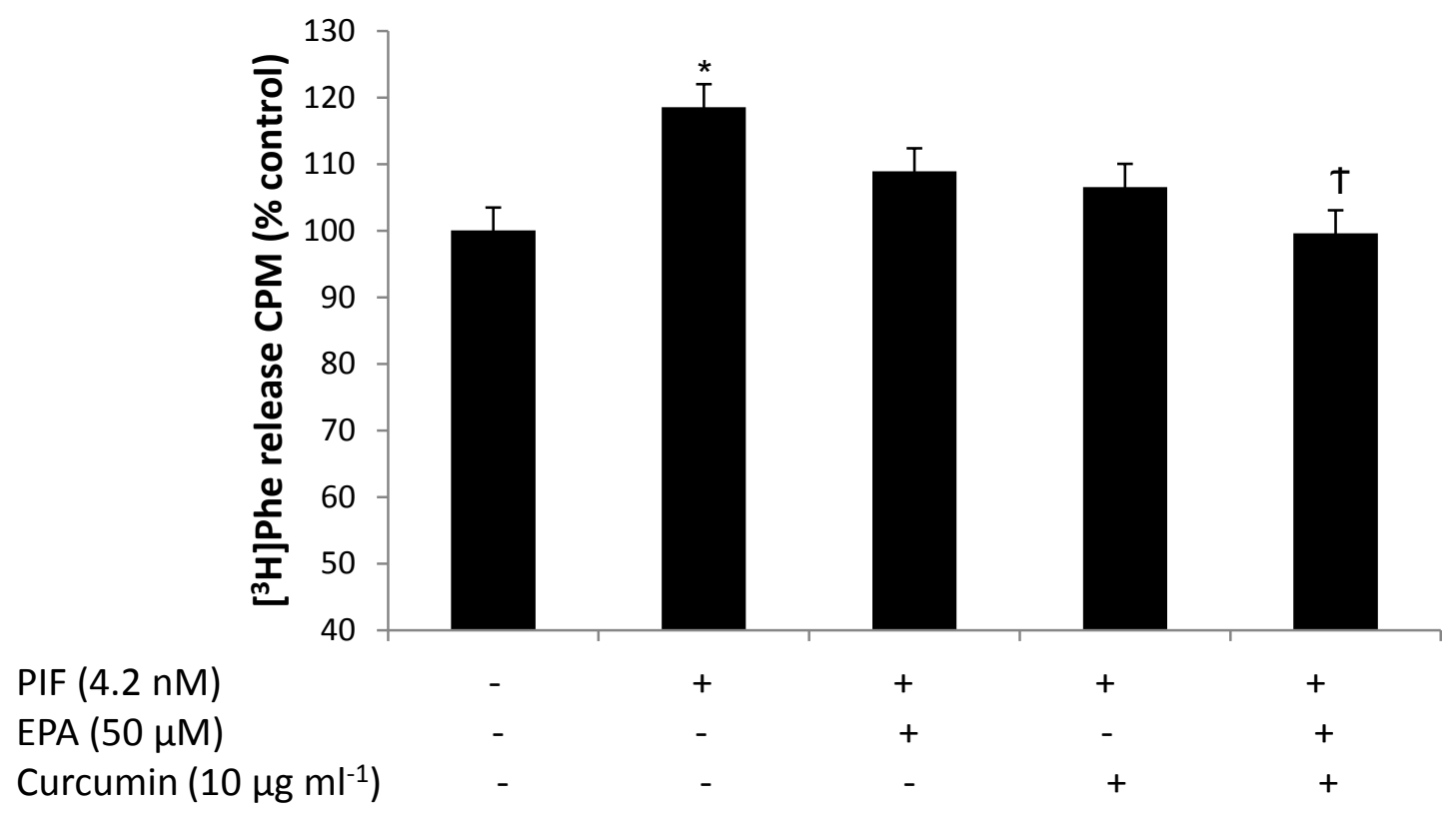


Fig 2B

B

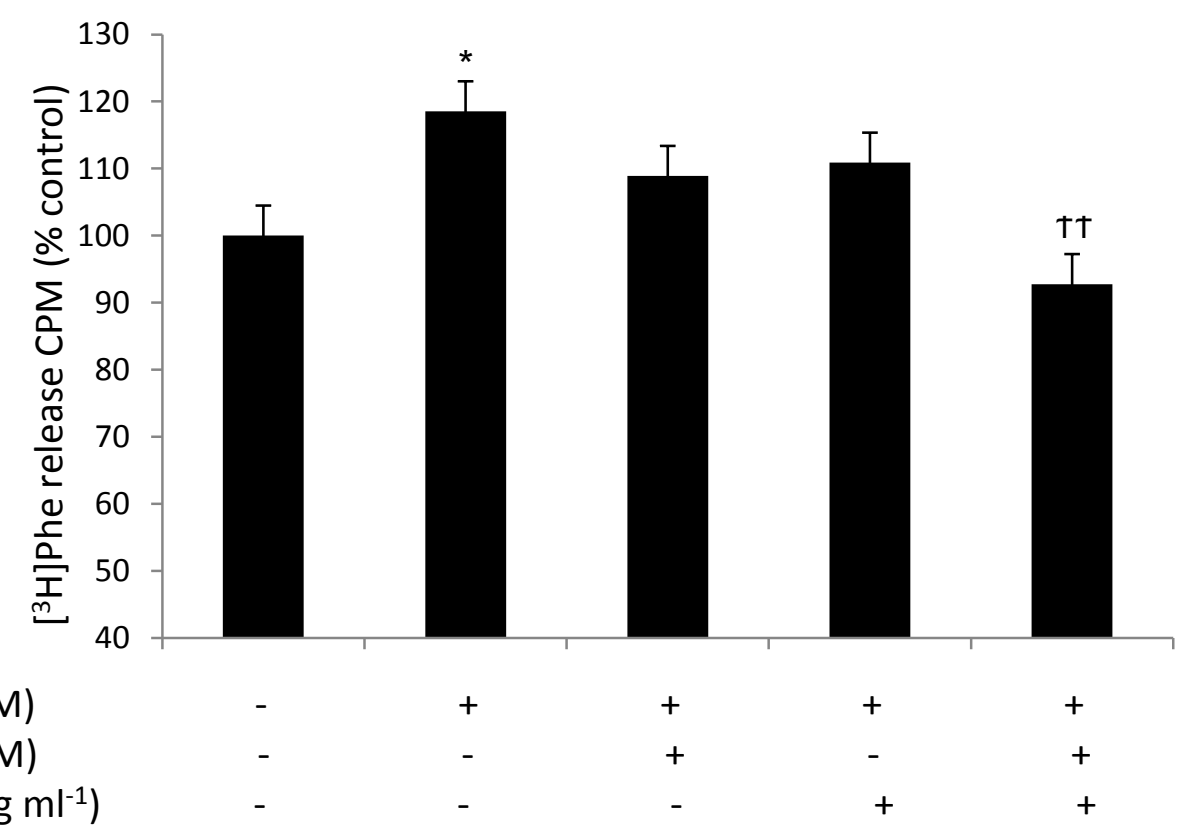


Fig $2 \mathrm{C}$

C

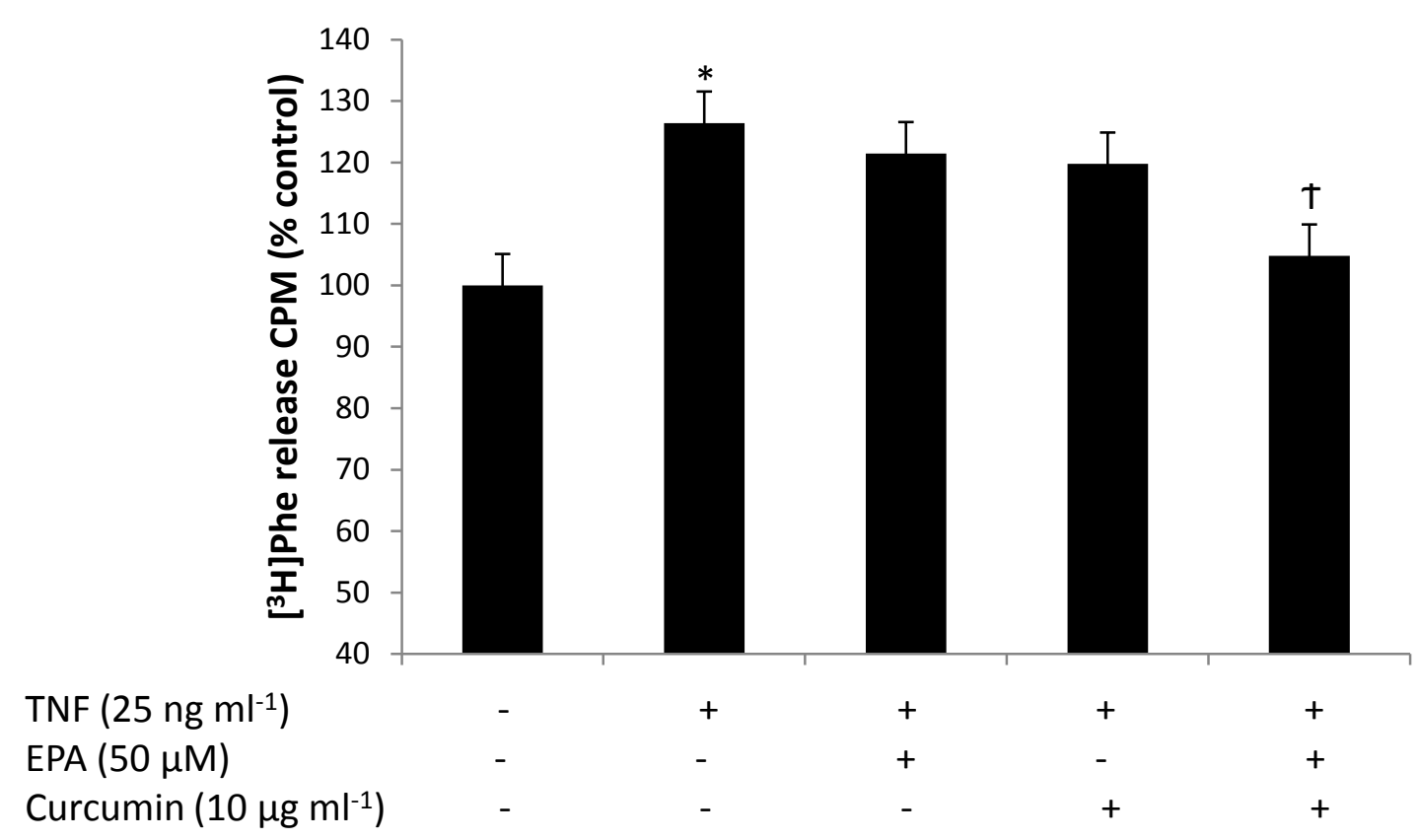


Fig 2D

D

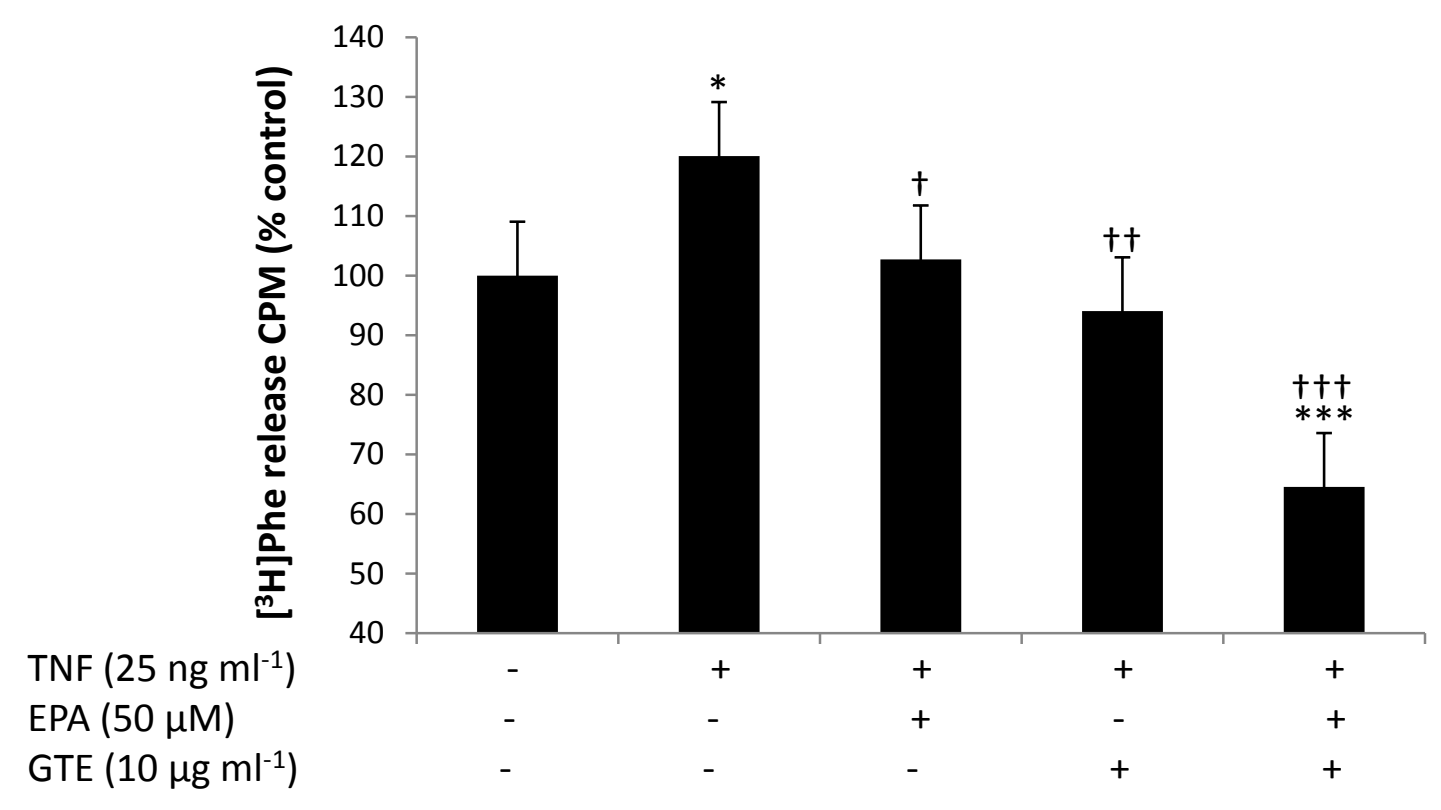


Fig $3 \mathrm{~A}$

A

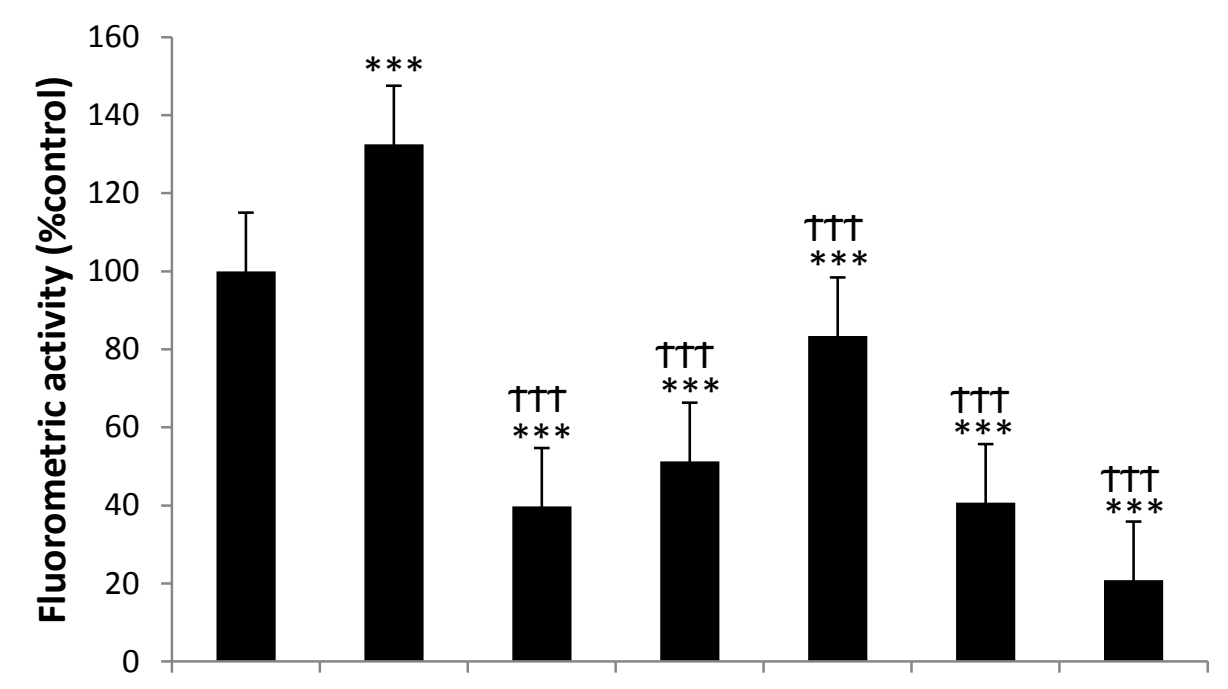

TNF (25 ng ml-1)

EPA $(50 \mu \mathrm{M})$

Curcumin $\left(10 \mu \mathrm{g} \mathrm{ml}^{-1}\right)$

GTE $\left(10 \mu \mathrm{g} \mathrm{ml}^{-1}\right)$ 
Fig 3B

B

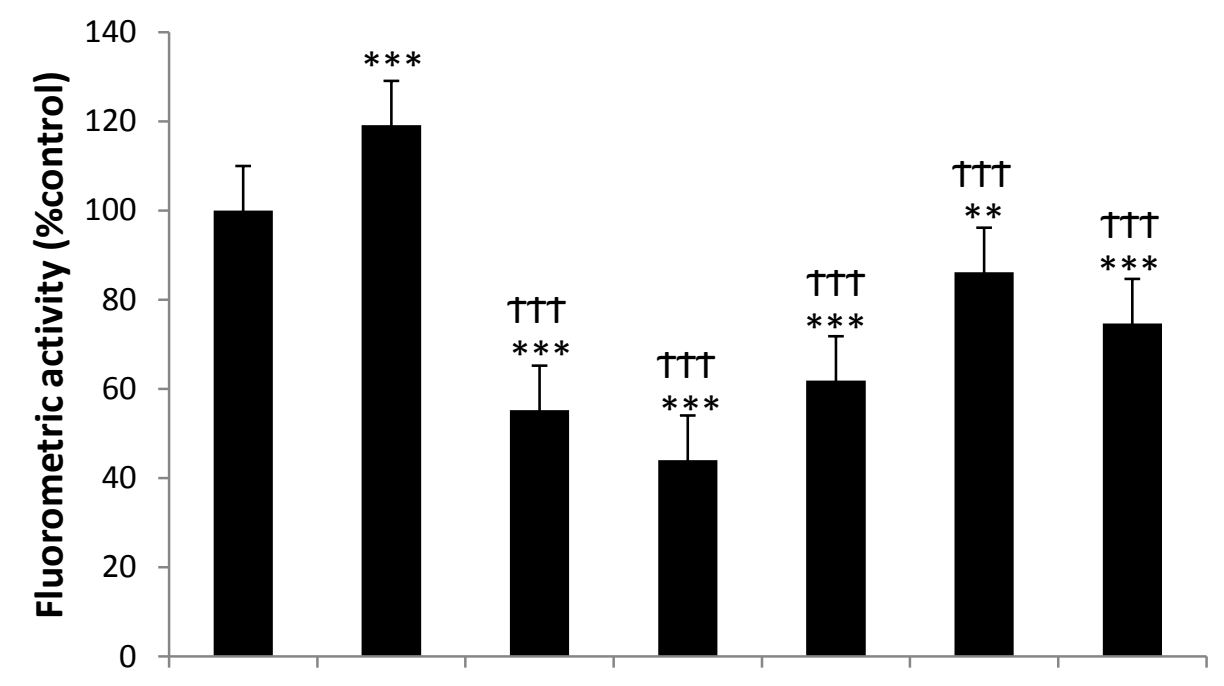

PIF (4.2 nM)

EPA $(50 \mu \mathrm{M})$

Curcumin $\left(10 \mu \mathrm{g} \mathrm{m}^{-1}\right)$

GTE $\left(10 \mu \mathrm{g} \mathrm{ml}^{-1}\right)$ 
Fig 4A
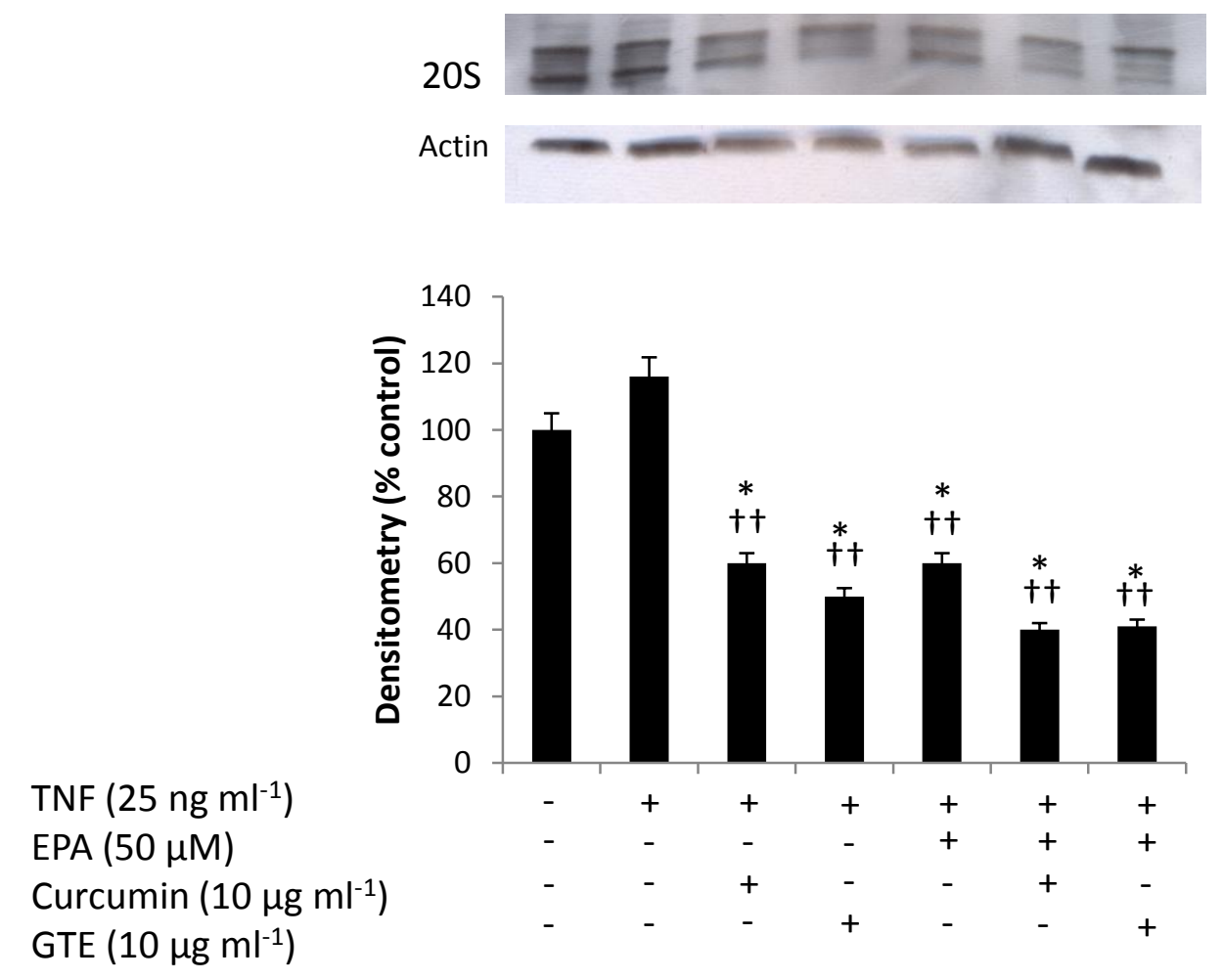
Fig 4B

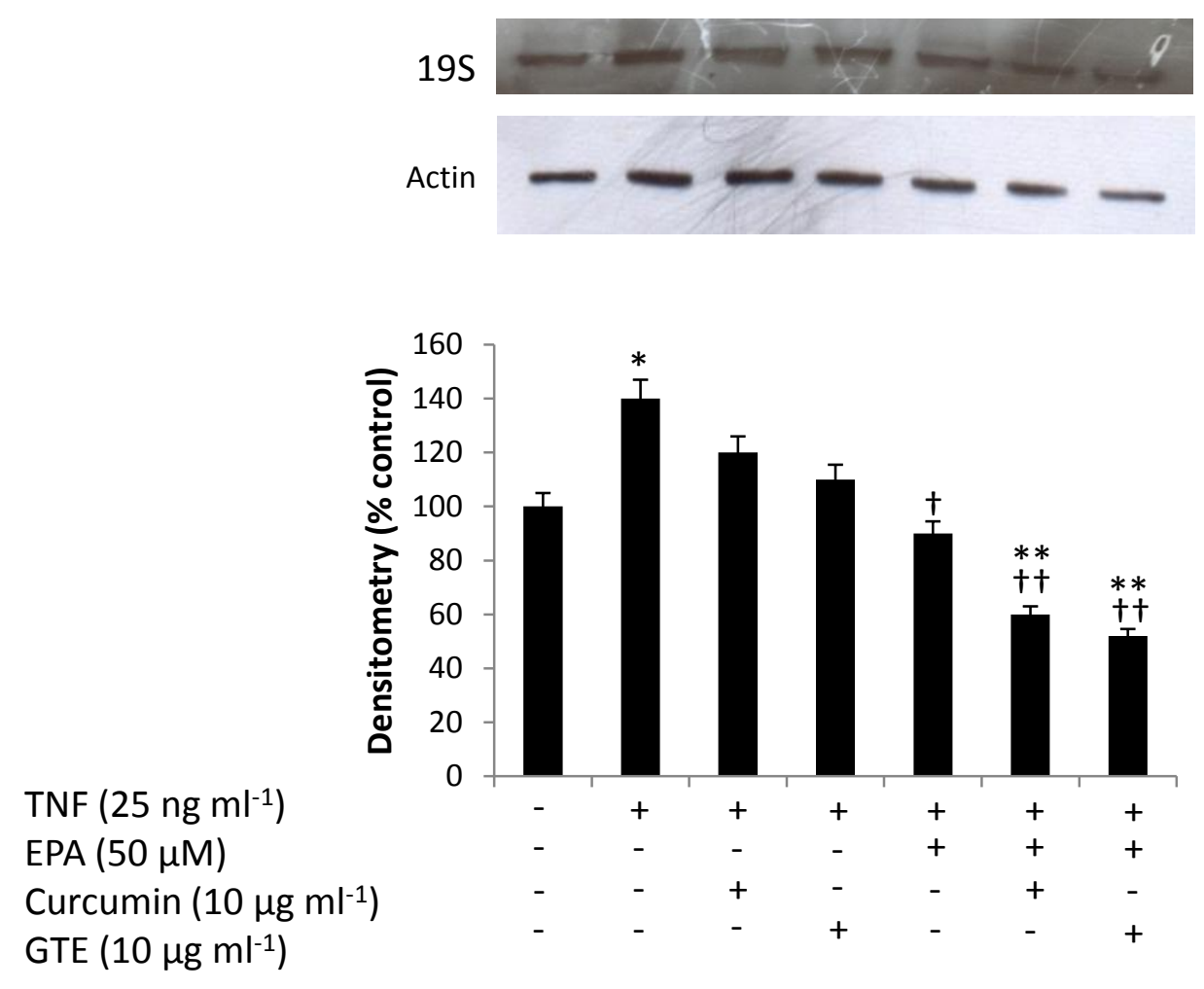


Fig 4C
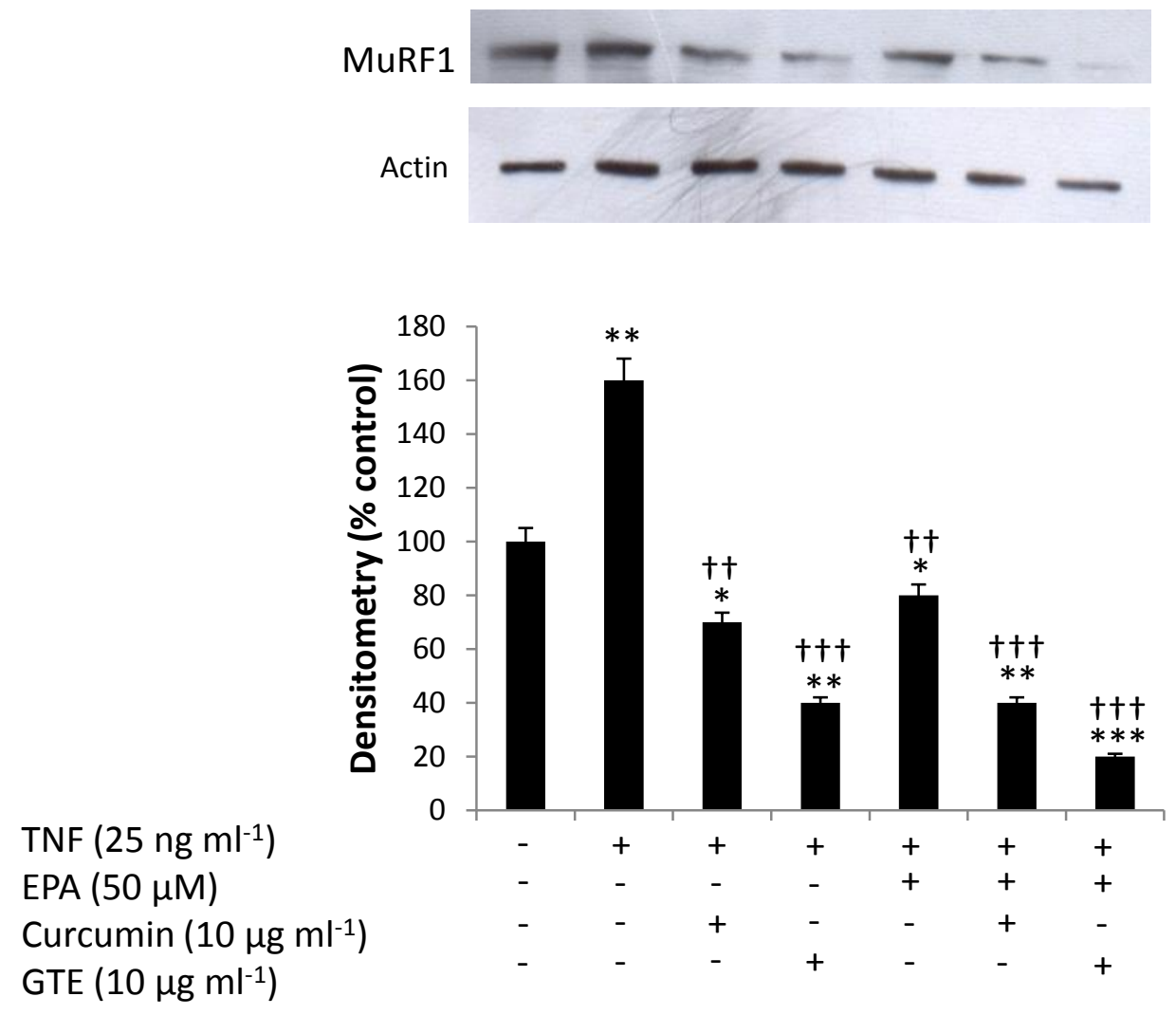
Fig 4D

MAFbx
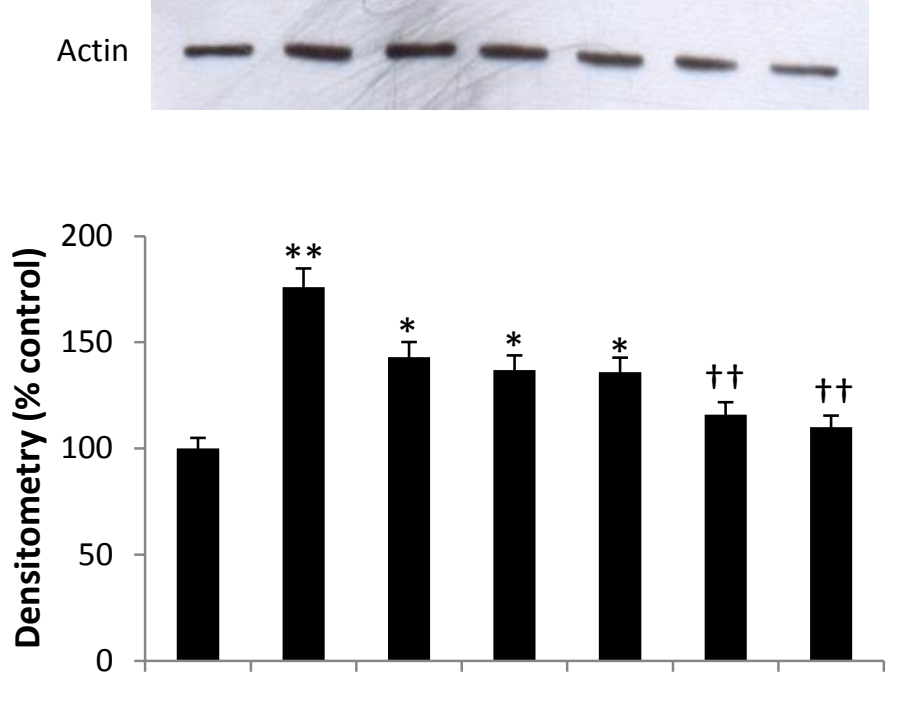

TNF (25 ng ml-1)

EPA $(50 \mu \mathrm{M})$

Curcumin $\left(10 \mu \mathrm{g} \mathrm{ml}^{-1}\right)$

GTE (10 $\left.\mathrm{g} \mathrm{ml}^{-1}\right)$ 
Fig 5A

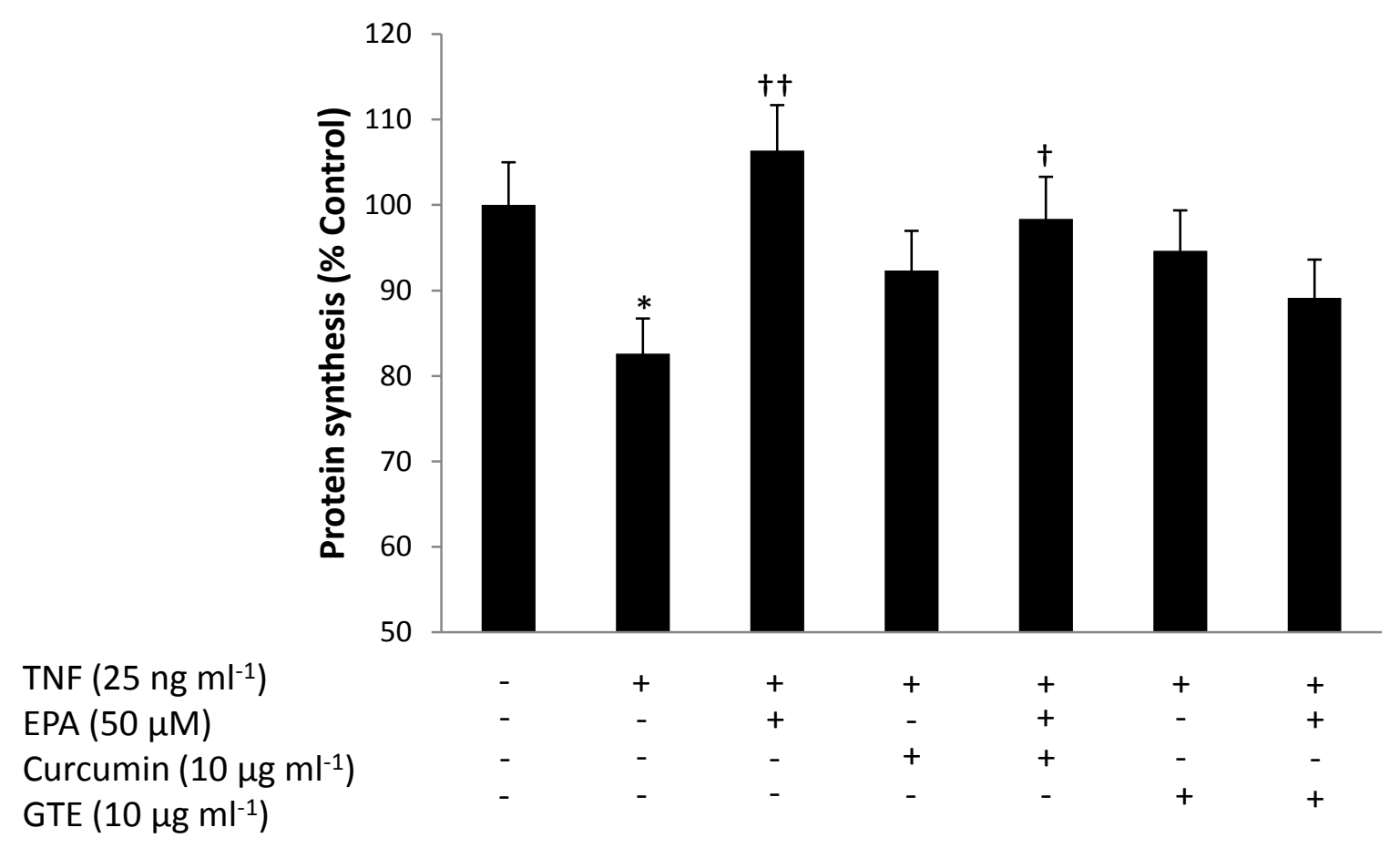


Fig 5B

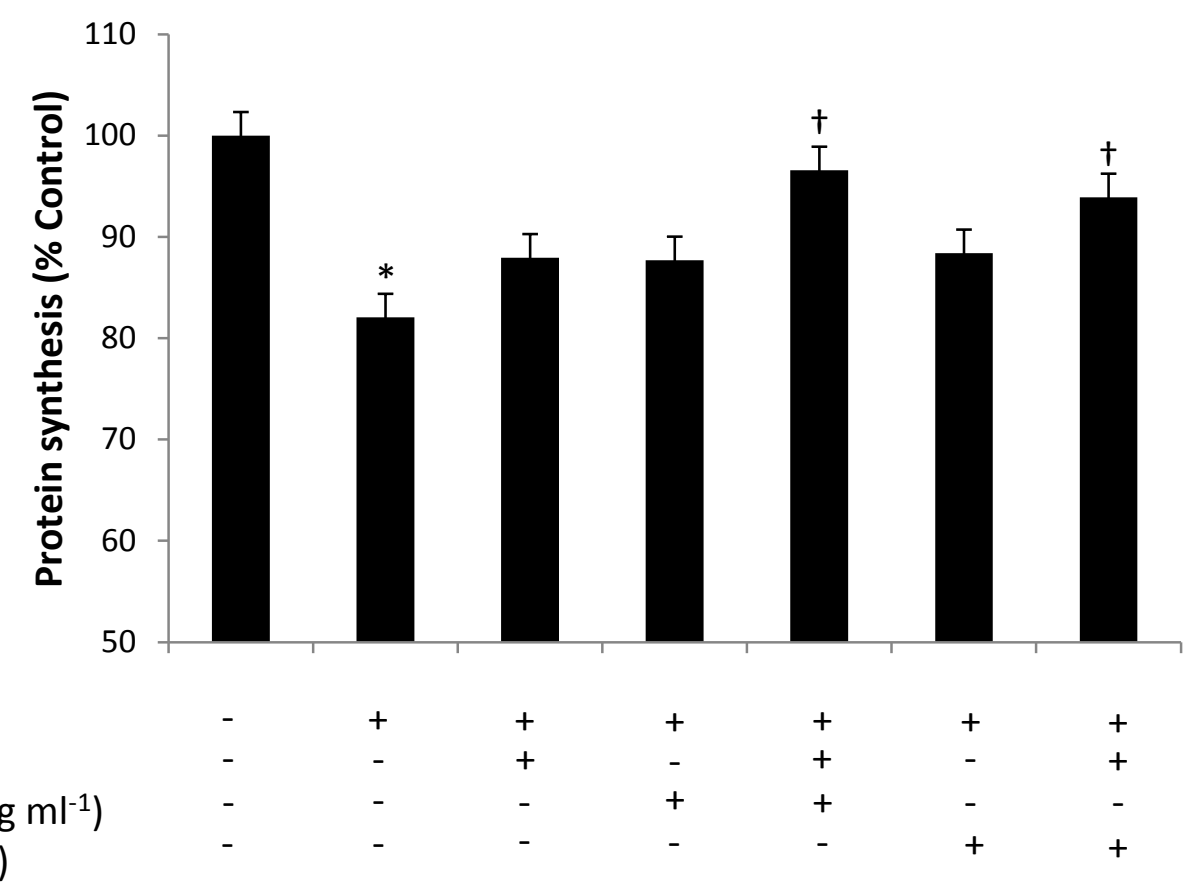

PIF (4.2 nM)

EPA $(50 \mu \mathrm{M})$

Curcumin $\left(10 \mu \mathrm{g} \mathrm{ml}^{-1}\right)$

GTE (10 $\mathrm{g} \mathrm{m}^{-1}$ ) 


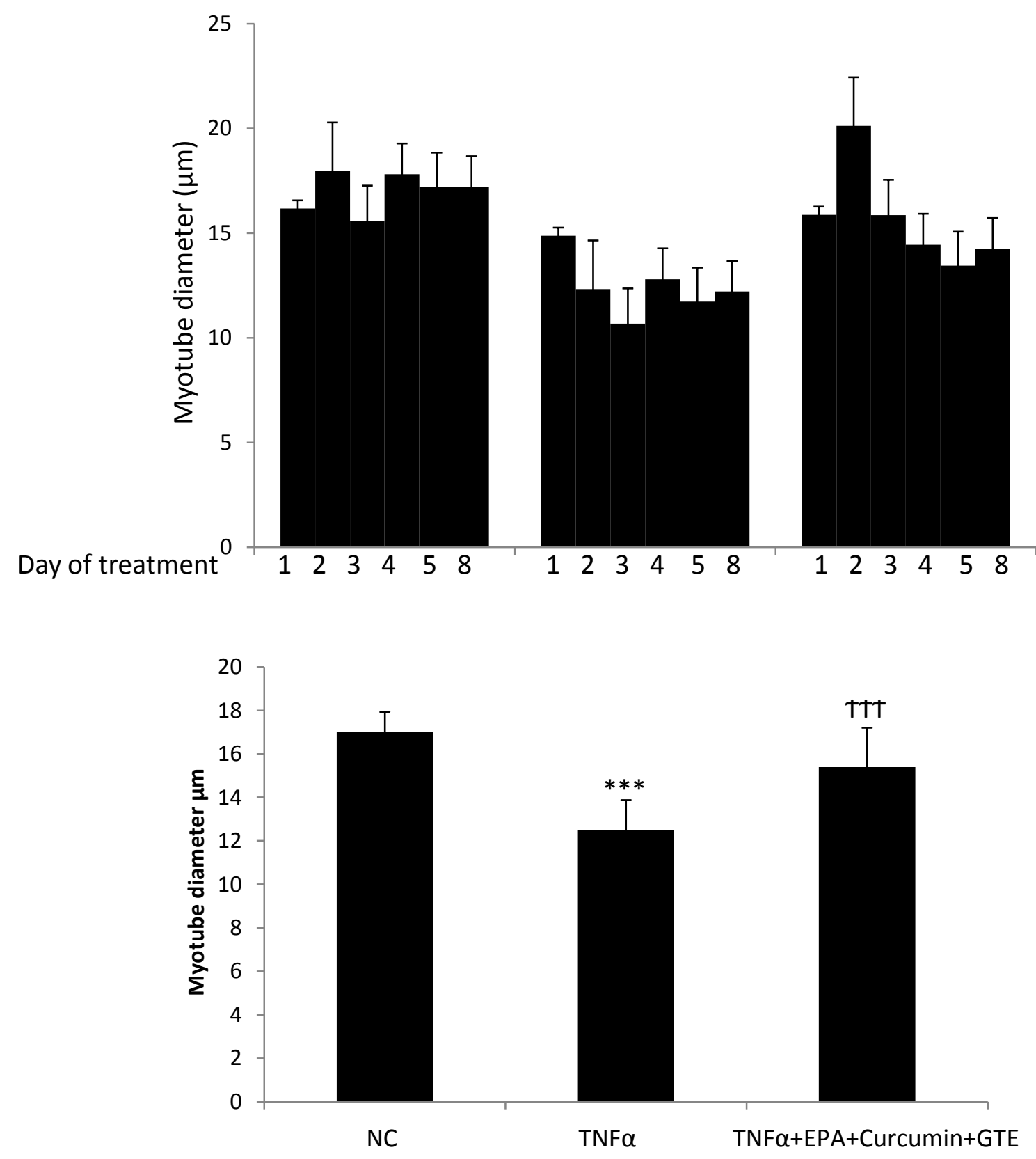

Fig 6A 


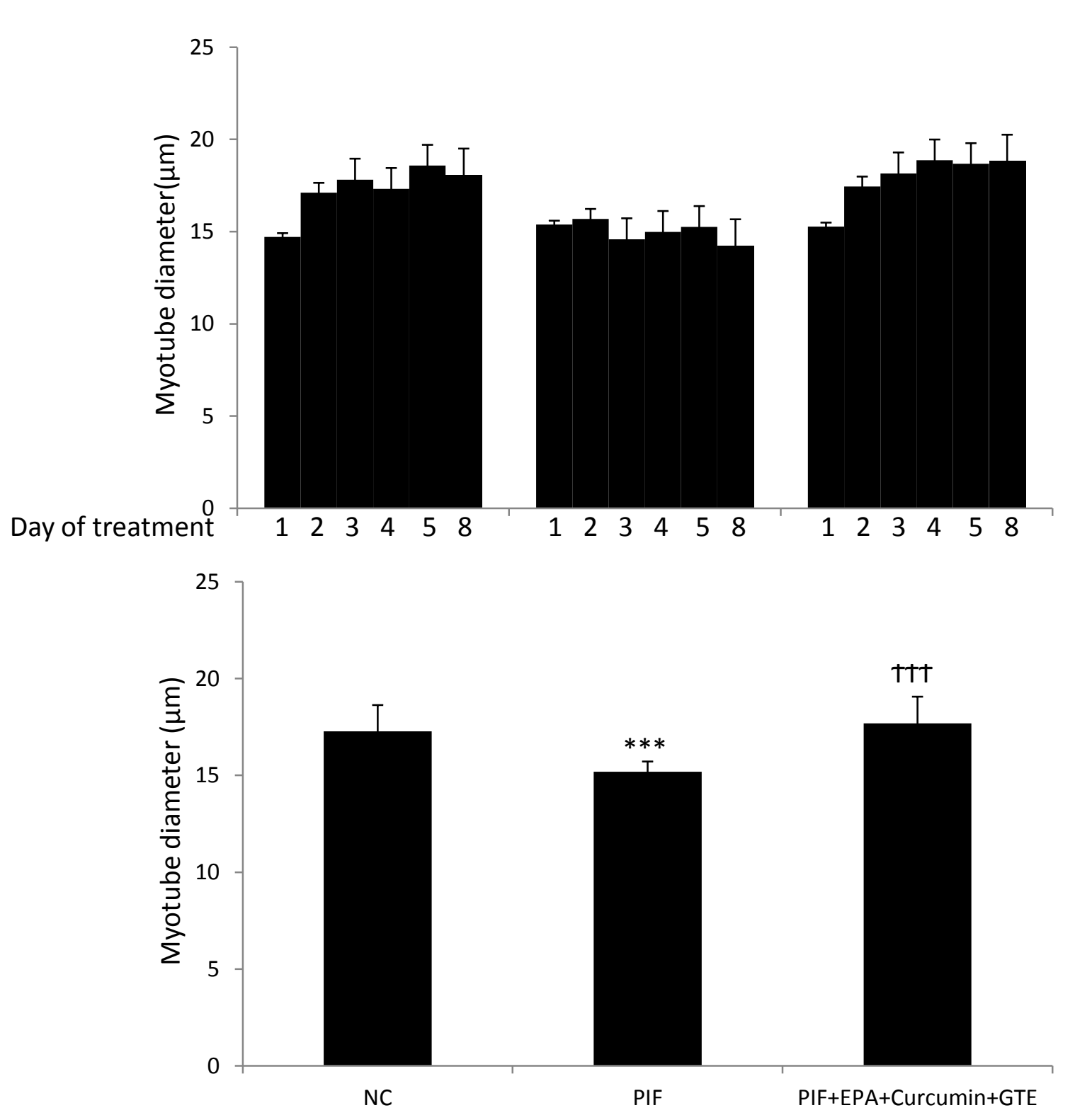

Fig 6B 